\title{
Pachydermodactyly: a Case Report and Literature Review
}

\author{
Mirjana PARAVINA ${ }^{1,2}$, Milenko STANOJEVIĆ ${ }^{1,2}$, \\ Dragan JOVANOVIĆ ${ }^{1,2}$ Dragana LJUBISAVLJEVIĆ ${ }^{2}$ \\ ${ }^{1}$ Medical Faculty, University of Niš, Serbia \\ ${ }^{2}$ Clinic of Skin and Venereal Diseases, Clinical Center of Niš, Serbia ${ }^{2}$ \\ *Correspondence: Mirjana Paravina, E-mail: mirjanaparavina@gmail.com
}

UDK 616.5:616.727.4

\section{DE GRUYTER OPEN}

\begin{abstract}
Pachydermodactyly is a rare, benign form of digital fibromatosis, characterized by asymptomatic and progressive, periarticular and usually symmetrical soft tissue finger swelling, specifically on the lateral aspects of the proximal interphalangeal joints mainly of the second, third, and fourth fingers; it mostly affects young adolescents and is probably due to repeated mechanical injury of the skin (such as repeated clasping or rubbing of crossed fingers), sometimes as a result of obsessive-compulsive disorder, which must be distinguished from obsessive "chewing pads". This paper presents a male patient aged 19, who presented with first symptoms at the age of 12 , and was diagnosed with periarticular hypertrophy: localized soft tissue thickening around the proximal interphalangeal joints of all fingers except the thumbs; slight hypertrophy of the skin; absence of subjective complaints; normal joint function. Dermatological status on admission revealed: symmetrical soft tissue swelling of all fingers of both hands except the thumbs at the level of the proximal interphalangeal joints; normal appearance of the distal parts of all fingers; thickening at the level of the proximal interphalangeal joints, bilateral, almost symmetrical hypertrophy (ulnar and radial) of phalanges of the affected fingers except both index fingers, affecting only the ulnar side. The skin lesions were pain-free on palpation, with homogeneous texture and elastic consistency, freely movable over underlying structures. The affected joints showed no functional deficit. The test results, sonography, radiography and histopathology confirmed our clinical diagnosis pachydermodactyly. The review of the currently available literature, published between 1973 and 2014, including 99 papers and 160 patients, provided important insight into the characteristics and variations of the disease.
\end{abstract}

\section{Key words}

Fibroma; Hand Dermatoses; Hand Deformities; Fingers; Soft Tissue Neoplasms; Cumulative Trauma Disorders

$\mathrm{P}$ achydermodactyly (PDD) is a benign digital fibromatosis characterized by asymptomatic and progressive, periarticular and usually symmetrical soft tissue finger swelling, specifically on the lateral aspects of the proximal interphalangeal joints mainly of the second, third, and fourth fingers: thus, it produces a symmetrical, diffuse swelling of the skin around the dorsal and lateral aspects of the proximal phalanges of the index, ring and middle fingers (1).

It particularly affects young adolescents and is probably due to repeated mechanical skin injury, sometimes as a result of obsessive- compulsive disorder, which must be distinguished from obsessive "chewing pads" $(1,2,3)$. Diffuse swelling of the digits, which includes the dermis as well as epidermis, clearly distinguishes PDD from "knuckle pads", calluses, occupational callosities, etc. Affected families have been reported, and pachydermodactyly and knuckle pads may coexist (1).

Pachydermodactyly was first described by Bazex et al. in 1973 as "pachydermie digitale" (4). Verbov named this entity as pachydermodactyly from the Greek pachy (thick), dermo (skin), and dactyly (finger) in 1975 (5). 


\section{Case Report}

This paper presents a male student aged 19, who developed thickening of the third and fourth fingers of the left hand at the age of 12. By the age of 14 , he presented with the same changes on all fingers except the thumbs, and since then the condition has not changed. He associated these changes with hitting the ball, as well as with the habit of repeated clasping or rubbing the fingers. After he underwent evaluation by an orthopedist, physiatrist and rheumatologist, he was referred to our Clinic with the diagnosis of periarticular arthropathy in order to exclude psoriasis and/or seborrheic scalp dermatitis. On admission, the patient denied any other disease or a family history.

On admission, the patient's general condition was good. Dermatological examination revealed: symmetrical soft tissue swelling of all fingers of both hands except the thumbs at the level of the proximal interphalangeal joints; normal appearance of the distal parts of all fingers; thickening at the level of the proximal interphalangeal joints, bilateral, almost symmetrical hypertrophy (ulnar and radial) of phalanges of the affected fingers except both index fingers, affecting only the ulnar side (Figure 1). The skin lesions were pain-free on palpation, with homogeneous texture and elastic consistency, freely movable over underlying structures. The affected joints showed no functional deficit.

\section{Laboratory and other test results}

All relevant laboratory test results were within reference values, including factors of inflammation, serum levels of immunoglobulins, C3 and C4 complement components, presence of antinuclear antibodies and immunoglobulins.

Ultrasonography of the hand joints: osteoarticular surfaces without signs of defects; there are no periarticular focal lesions, except for imbibition of the soft tissues; synovial thickening of the medial interphalangeal joints; intra-articular synovial fluid volume is increased.

$\mathrm{X}$-rays of the hands (both directions) did not reveal any involvement of the bones structures (Figure 2).

Histopathological findings: severe epidermal hyperkeratosis and acanthosis; dermoepidermal junction is flat; dermis is thickened and hypocellular,

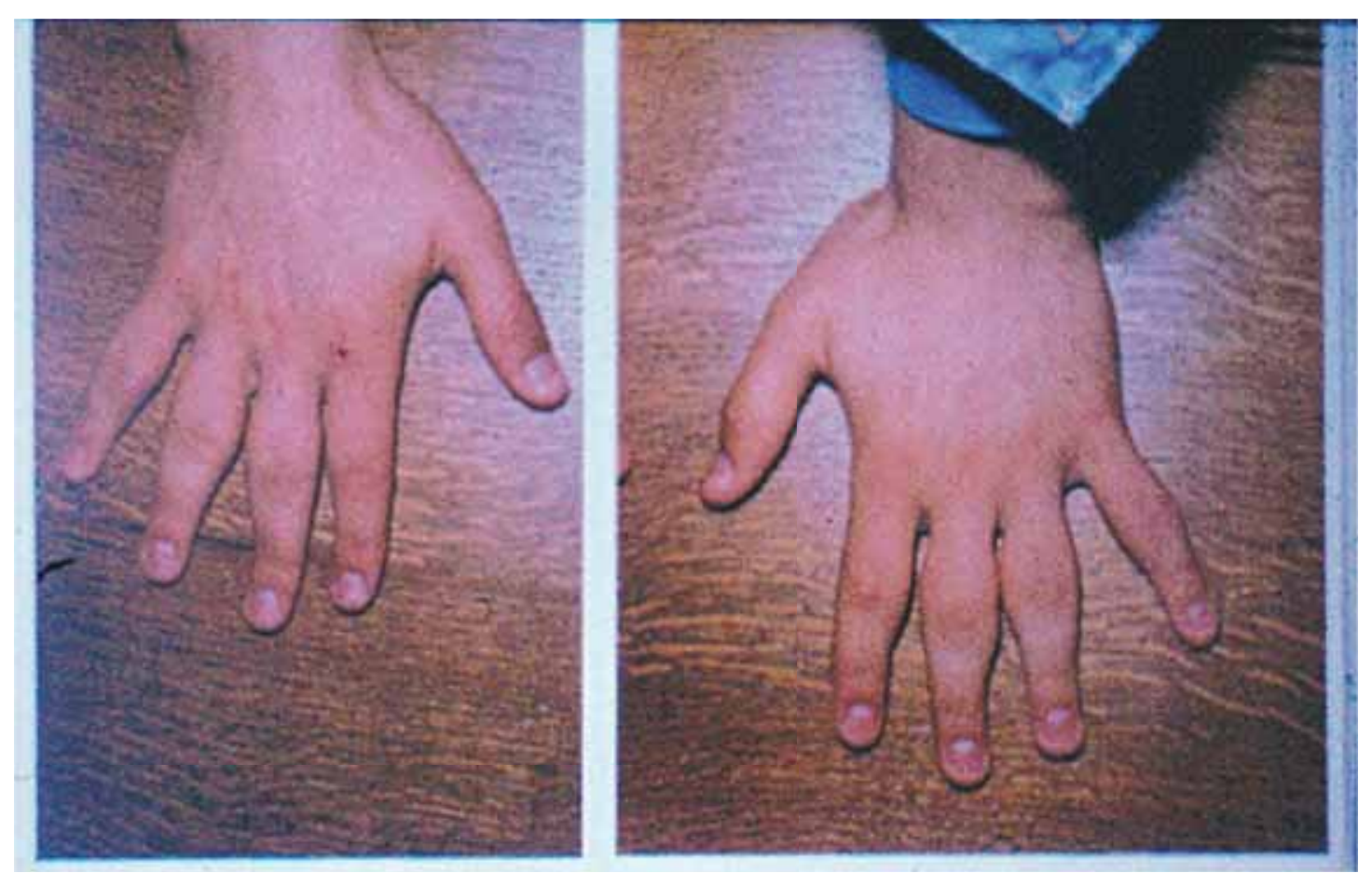

Figure 1. A symmetrical, diffuse swelling around both lateral (ulnar and radial) aspects of the proximal phalanges of the small, ring and middle fingers; proximal phalanges of both index fingers affected only around the ulnar aspects; distal parts without involvement 


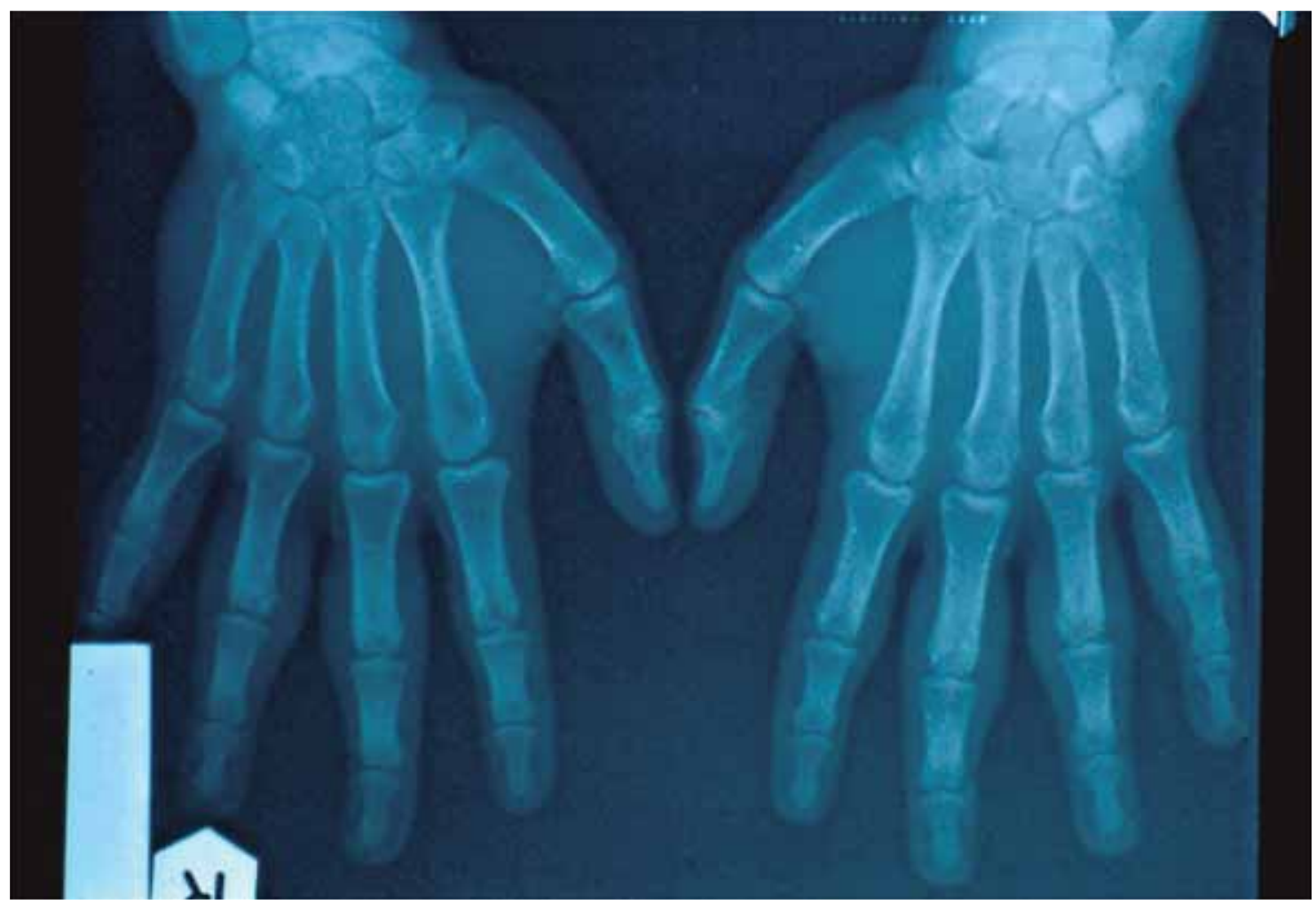

Figure 2. Hand x-ray: preserved bone structure

rare fibroblasts accompanied by hyalinized collagenous stroma; absence of adnexal skin structures.

\section{Therapy}

Intralesional triamcinolone solution injections during three months resulted in slight reduction of swelling of the treated finger. The patient was advised to avoid mechanical trauma, rubbing and cracking of the fingers.

\section{Discussion and literature review}

Pachydermodactyly is a condition which mostly occurs in adolescents and is characterized by asymptomatic soft tissue swelling, specifically on the lateral aspect of the proximal interphalangeal (PIP) joints of the hands, and skin lesions. Its diagnosis and treatment requires expertise of various health professionals (rheumatologists, orthopedic surgeons, pediatricians, dermatologists, surgeons). Papers on PDD are published in journals that are not exclusively focused on dermatology, probably because patients with PDD require a multidisciplinary approach (Table 1 ). Two papers represent a comprehensive analysis of previously published papers: the first published in 2009 by Beltraminelli et al. (2), and the second published in 2014 by Dallos et al. (3). The first paper analyzed 55 papers including 88 patients, while the other included 17 more papers, with a total of 121 patients reported until then. Our research found 27 more papers (41, $46,48,49,54,55,57,59,62,69,70,73,74,78$, $79,83,85,86,88,89,92,93,95-98,100)$ including 39 patients. So, since Bazex and associates to date, at least 99 papers including 160 patients have been published on PDD. Our case report is the $100^{\text {rd }}$, and our patient the $161^{\text {st }}$. These papers are listed in the references, mostly in order of publication, except for authors from the beginning of this paper.

The characteristic features of the disease, described in certain number of patients, are shown in Table 2, based on the table of Dallos et al. (3). Although PDD may be considered a rare condition, one must not neglect clinical features that are at the same time factors responsible for not recognizing the disease (62), such as the absence of subjective symptoms, self limiting course, regression during adolescence, absence of permanent sequelae. For this 
Table 1. Types of journals reporting patients with pachydermodactyly

\begin{tabular}{lcc} 
Journal & No. of reports & References \\
Dermatology & 60 & $2,4-62$ \\
\hline Rheumatology & 18 & $3,63-79$ \\
\hline Surgical & 4 & $80-83$ \\
\hline Pediatric & 6 & $84-89$ \\
\hline Orthopedic & 3 & $90-92$ \\
\hline Other & 8 & $93-100$ \\
\hline Total & 99 & $2-100$
\end{tabular}

reason, the actual prevalence of PDD is estimated to be much higher $(2,3)$.

The disease commonly affects boys around puberty, as in our patient $(2,44,76)$; PDD at older age may be due to non-recognition of the disease (3). The medical literature describes two cases of PDD since birth $(13,27)$, and only four cases in the elderly (36). The condition occurs sporadically, but familial cases have also been reported $(8,21,24,36,42,93)$, and in three cases it was a transgradient form of PDD $(14,19,36)$.

The exact etiology of pachydermodactyly is unknown; it may include genetic predisposition, probably essential, associated with precipitating factors (3). It is probably due to repeated mechanical injury such as tics, stretching, rubbing or cracking of the fingers, both in healthy or people with obsessivecompulsive disorders $(19,20,26,35,38,39,47$, $51,62,84,85,96)$. PDD may occur due to repeated mechanical trauma in poultry processing workers, farm workers, those whose work is computer-related (52, 56, 58, 77); in athletes (football, handball, fencing) $(61,71)$, or musicians playing the guitar or flute (69); excessive use of computers by adolescent boys also contributes to appearance of $\operatorname{PDD}(53,76)$. However, there are reports on patients with PDD unpreceded by friction or trauma $(8,10,49,74,100)$. PDD is significantly more common in boys at the beginning of puberty compared to females and older children, supporting the role of androgen hormones in its pathogenesis; the possible impact of the growth hormone and hypothyroid function should not be excluded (3).

Due to frequent occurrence of PDD in persons with obsessive compulsive and neurological disorders, there are authors who think that PDD should be on the list of skin manifestations of psychological problems (2, 26, 51). Our patient presented with a habit of rubbing and cracking of fingers, but had no psychological disorders.

Although a typical clinical picture includes benign asymptomatic soft tissue thickening on the lateral (ulnar and radial) proximal interphalangeal joints of the II, III and IV fingers of both hands, there are deviations, as in our patient whose both little fingers were affected, as well as the ulnar sides of both index fingers. Dorsal and/or ventral sides of fingers can also be affected $(23,29,31,94)$. Distal involvement has also been described affecting distal phalanges $(37,42,45)$, as well as metacarpophalangeal joints $(16,40)$, with fibromatous thickening or rigid nodes (83). These lesions are usually symmetrical (88), but may be asymmetrical to a certain point, varying in the number and extent of affected joints on the left and right hand $(76,97)$ or affecting only some joints, the so-called localized form of PDD (13). There are reports on the monoarticular form of PDD $(32,65)$. The thumbs and fifth fingers are rarely 
Tabela 2. Reported patients with pachydermodactyly

Reference

Demographic data

No. of patients

male/female
Dallos T, et al. (3)

$\mathrm{n}=121$

$(79) /(21)$
Current review

$\mathrm{n}=31$

$26(84) / 5(16)$

\section{Disease characteristics}

No. of patients

$\mathrm{n}=121$

$\mathrm{n}=22$

Disease onset: median age (y) (range)

$14(5-74)$

$13(4-20)$

Course of disease: median (y) (range)

$2.5(0.25-15)$

$3.5(1-12)$

Clinical signs and symptoms

\begin{tabular}{lcc}
\hline No. of patients & $\mathrm{n}=121$ & $\mathrm{n}=22$ \\
Thickening: $\mathrm{n}(\%)$ & $121(100)$ & $31(100 \%)$ \\
Restriction of movement (n (\%) & $(2.5)$ & $0(0)$ \\
Subjective complaints: $\mathrm{n}(\%)$ & $(5)$ & $0(0)$ \\
Itching: $\mathrm{n}(\%)$ & $(2.5)$ & $0(0)$ \\
Pain: $\mathrm{n}(\%)$ & $\mathrm{NA}$ & $\mathrm{n}=31$ \\
\hline Etiology & $\mathrm{n}=121$ & $12(39)$ \\
\hline No. of patients & $(44)$ & $8(26)$ \\
Identified mechanical injury: $\mathrm{n}(\%)$ & $(15)$ & $0(0)$ \\
Psychological and/or psychiatric diseases: $\mathrm{n}(\%)$ & $(5)$ & \\
\hline Positive family history: $\mathrm{n}(\%)$ &
\end{tabular}

$\mathrm{n}$, number of patients; $y$, year; NA, not available

affected $(6,8,21,50,80,99)$. Toes are never affected, whereas plantar pachydermia was described in a patient with PDD and acrocyanosis (39). Sometimes the skin shows lichenification, fine desquamation or hyperkeratosis, even moderate erythematosis (27), but it is rarely painful $(9,10,17)$. No cases with hypersensitivity, itching, burning, morning stiffness or reduced mobility have been reported $(3,48,73$, 91). Only one case of deforming PDD was reported with nonerosive interphalangeal joint subluxation 
(72). Our patient presented with involvement of both lateral aspects, ulnar and radial parts of the proximal interphalangeal joints and proximal phalanges of the II, III, IV and V fingers of both hands, except the index fingers, where only ulnar sides were affected. The skin surface was slightly hyperkeratotic. He had no pain or functional limitations.

Pachydermodactyly has been described in association with Dupuytren's contracture (90), Asperger syndrome (38), Ehlers-Danlos syndrome (33), carpal tunnel syndrome and tuberous sclerosis $(13,33,36)$, gynecomastia (10), foot syndactyly (2), acute atrophia maculosa varioliformis (25), and Tourette's syndrome (59).

Due to the heterogeneous clinical picture and described familial cases, a classification with five different forms was proposed (36):

1. classical pachydermodactyly (several proximal interphalangeal (PIP) joints affected, frequently associated with mechanical trauma)

2. localized (one joint affected - monopachydermodactyly)

3. transgrediens pachydermodactyly (extension to the palms or metacarpophalangeal joints)

4. familial pachydermodactyly (affecting several family members)

5. pachydermodactyly associated with tuberous sclerosis.

\section{Diagnosis}

Laboratory findings show no specific changes. Plain radiography shows soft tissue thickening, without bone, tendon or capsular changes such as periostosis, periarticular osteoporosis, erosions, cysts or osteophytes $(3,55)$. Magnetic resonance imaging reveals only soft tissue swelling, and typical fusiform swelling (without effusion, synovitis, tendonitis, hypervascularization and without bone involvement) $(53,57,68,70,71)$.

Histologically, there is hyperkeratosis, acanthosis, thickening of the dermis, increase in fibroblasts and collagen deposits; increase in the thickness of basal membrane and of eccrine sudoriparous glands, intense deposition of mucopolysaccharides, poor demarcation between the papillary and reticular dermis, mucin deposition between collagen fibers $(7,11,30,34$, $43,53,60,70,82,83,90,95,96)$. Types III and V collagen are increased with a reduction of collagen type I. Electron microscopy shows an increased number of fine-diameter collagen fibers $(21,30,34,36)$, less uniform $(12,64)$. Some authors believe that histology is not mandatory for diagnosis (55), as well as many useless and expensive diagnostic tests $(54,89)$.

Chen and associates (99) proposed the following diagnostic criteria:

- the patient has no symptoms

- morning stiffness is absent

- pain on motion and tenderness to palpation is absent

- finger swelling is radial or ulnar in location, rather than circumferential

- laboratory test results are unremarkable

- plain radiographs show only soft tissue swelling.

With these typical findings, additional investigations, such as MRI or skin biopsy, are rarely needed to establish a diagnosis of PDD.

It is of great importance to distinguish PDD from other diseases of this localization. Differential diagnosis should include: rheumatic diseases, primarily juvenile idiopathic arthritis, rheumatoid arthritis, rheumatoid nodules; bone diseases such as secondary pachydermoperiostosis, ostitis cystoides multiplex Jüngling, spina ventosa; skin diseases, often knuckle pads with circumscribed keratoses that overly the finger joints with highly hyperkeratotic epidermis and hyperplastic dermal connective tissue, pseudo knuckle pads, foreign-body granulomas, collagenous plaques of the hands, infantile or juvenile digital fibromatosis, progressive nodular skin fibrosis, psoriatic acropachydermodactyly, connective tissue nevi; endocrine disorders, thyroid acropachy, acromegaly; tumors, primarily fibromas, sarcomas, paraneoplastic acropachydermodactyly; hereditary diseases, such as tuberous sclerosis, primary pachydermoperiostosis, Thiemann disease $(3,41,55,66,67)$. PDD is commonly misdiagnosed as a rheumatologic condition (100), namely juvenile idiopathic arthritis $(63,69,70,78$, $89,86)$, which may lead to unnecessary treatment (78). Pereira and associates discussed similarities (mechanical irritation, favorable effects of intralesional triamcinolone injections) and differences (epidermal and dermal response) between knuckle pads and PDD (41). 


\section{Treatment}

There is no effective medical treatment for PDD at this time $(2,25)$. Surgical excision of fibrous tissues may be a good therapeutic option $(3,46,80)$ without recurrence (75). Good results are obtained using intralesional triamcinolone injections $(10,22,100)$, while topical therapy with corticosteroids is mostly ineffective. Higuchi reported good therapeutic results after using tranilast, an anti-allergy agent which inhibits collagen synthesis in human skin fibroblasts (300 mg daily for 6 months) (92). Elimination of mechanical irritation may lead to spontaneous regression $(2,15,18,20,71,81,91,99)$. Patients with PDD should avoid mechanical irritation, receive adequate care and monitoring, whereas invasive procedures are not recommended $(3,74)$. Protective gloves and bandages are proposed to prevent mechanical irritation (44). Patients with obsessive compulsive disorders may need psychiatric help.

Pachydermodactyly is a benign condition with a chronic course. The prognosis is variable. After longterm progression, regression may occur at a later age (97).

\section{Conclusion}

We report a case of a male patient who developed symptoms of pachydermodactyly around puberty as a progressive soft tissue thickening around the proximal interphalangeal joints of all fingers except the thumbs probably due to stretching, rubbing or cracking of the fingers. There was no family history. Intralesional triamcinolone solution injections during three months resulted in slight reduction of swelling of the treated finger. The patient was advised to avoid mechanical trauma, rubbing and cracking of the fingers. A review of the available literature from 1973 to 2014 provided important insight into the characteristics and variations of the disease.

\section{Abbreviations}

$$
\begin{aligned}
& \text { PDD - pachydermodactyly } \\
& \text { PIP - proximal interphalangeal } \\
& \text { MRI - Magnetic resonance imaging }
\end{aligned}
$$

\section{References:}

1. Burrows NP, Lovell CR. Disorders of connective tissue. In: Burns T, Breathnacht S, Cox N, Griffiths C, editors. Rook`s textbook of dermatology. 8th ed. Oxford: Wiley-Blackwell; 2010. p. 45.1-45.70.

2. Beltraminelli H, Itin P. Pachydermodactyly - just a sign of emotional distress. Eur J Dermatol 2009;19:5-13.

3. Dallos T, Oppl B, Kovacs L, Zwerina J. Pachydermodactyly: a review. Curr Rheumatol Rep 2014;16:442.

4. Bazex A, Dupre A, Teillard J. Pachydermie digitale des premieres phalanges par hyperplasie conjonctive dermique et aplasie hypodermique. Bull Soc FR Dermatol Syphiligr 1973;80:455-8.

5. Verbov J. Letter: Pachydermodactyly: a variant of the true knuckle pad. Arch Dermatol 1975;111:524.

6. Meigel WN, Plewig G. Kauschwielen, eine variante der Fingerknochelpolster. Hautarzt 1976; 27:391-5.

7. Garrel J, Sonneck JM, Neveux Y, Millet P, Doss N, Lanternier G. Pachydermie digitale isolee. Ann Dermatol Venereol 1982;109:769-70.

8. Kouskoukis CE. Stump the experts. Skin neoplasms. J Dermatol Surg Oncol 1985;11:585, 641.

9. Hudson PM. Pachydermodactyly. Br J Dermatol 1989;121(Suppl s34):111.

10. Curley RK, Hudson PM, Marsden RA. Pachydermodactyly: a rare form of digital fibromatosis - report of four cases. Clin Exp Dermatol 1991;16:121-3.

11. Chevrant-Breton J, Patoux-Pibouin M, Le Hir I, Renault A, Le Gall F. Pachydermodactyly: two new cases (abstract). In: Proceedings of the 2nd European Academy of Dermatology and Venereology Congress; 1991 Sep 9-12; Athens, Greece. European Academy of Dermatology and Venereology; 1991. p. 298.

12. Draluck JC, Kopf AW, Hodak E. Pachydermodactyly: first report in a woman. J Am Acad Dermatol 1992;27(2 Pt 2):303-5.

13. Lo WL, Wong CK. Localized pachydermodactyly in tuberous sclerosis. Clin Exp Dermatol 1993;18:146-7.

14. Sola A, Vazquez-Doval J, Sola J, Quintanillae E. Pachydermodactyly transgrediens. Int J Dermatol 1992;31:796-7.

15. Iraci S, Bianchi L, Innocenzi D, Tomassoli M, Nini G. Pachydermodactyly: a case of an unusual type of reactive digital fibromatosis. Arch Dermatol 1993; 129:247-8.

16. Aloi F, Solaroli C, Tomasini C. Pachidermodactilia e cuscinetti delle falangi: dermatosi autoprovocate? G Ital Dermatol Venereol 1993;128:393-7.

17. Bardazzi F, Fanti PA, de Padova MP, Varrotti C. Localized pachydermodactyly in a woman. Acta Derm Venereol 1994;74:152-3.

18. Lautenschlager S, Itin PH, Rufli T. Pachydermodactyly: reflecting obsessive- compulsive behavior? Arch Dermatol 1994;130:387.

19. Yanguas I, Goday JJ, Soloeta R. Pachydermodactyly: report of two cases. Acta Derm Venereol 1994;74:217-8.

20. Hagedorn M, Graf HG, Grosshans E. Pachydermodactyly - sequela of obsessive-compulsive neurosis. Hautarzt 1994;45:88-90.

21. Dupin N, Gautier MS, Rabary G, Auffret N, Beltzer-Garelly E, Binet O. Pachydermodactyly. Ann Dermatol Venereol 1994;121:632-4.

22. Meunier L, Pailler C, Barneon G, Meynadier J. Pachydermodactyly or acquired digital fibromatosis. Br J Dermatol 1994;131:744-6. 
23. Wollina U, Rulke D. Kauschwielen (chewing pads). Z Hautkr 1994;69:331-3.

24. Russo F, Rodriguez-Pichardo A, Camacho F. Familial pachydermodactyly. Acta Derm Venereol 1994;74:386-7.

25. Callot V, Wechsler J, Hovnanian A, RevuzJ. Pachydermodactyly and atrophia maculosa varioliformis cutis. Dermatology 1995; 190:56-8.

26. Itin PH, Lautenschlager S. Pachydermodactyly: a psychocutaneous disorder. Dermatology 1995;190:1-3.

27. Perez B, Gomez MI, Sanchez E, Munoz E, Ledo A. Pachydermodactyly: a case report. J Dermatol 1995;22:43-5.

28. Paricio JF, Lopez MA, Garcia GJ, Martin R, Gimenez H, Carapeto FJ. Pachydermodactyly limited to one finger. Eur J Dermatol 1995;5:338-9.

29. Kopera D, Soyer HP, Kerl H. An update on pachydermodactyly and a report of three additional cases. $\mathrm{Br} \mathrm{J}$ Dermatol 1995;133:433-7.

30. Kim TH, Cho YH, Park HB. Two cases of pachydermodactyly. J Dermatol 1996;23:419-24.

31. BalassianoV, Sodre CT, Ramos-e-Silva M. Pachydermodactyly: report of a case. J Eur Acad Dermatol Venereol 1996;6:260-3.

32. Veraldi S, Rizzitelli G, Brusasco A, Giannotti R. Pachydermodactyly of a single finger. Eur J Dermatol 1996;6:576-8.

33. Bardazzi F, Neri I, Fanti PA, Patrizi A. Pachydermodactyly in two young girls. Pediatr Dermatol 1996;13:288-91.

34. Kang BD, Hong SH, Kim IH, Kim WK, Oh CH. Two cases of pachydermodactyly. Int J Dermatol 1997;36:764-78.

35. Krasovec M, Elsner P. Pachydermodactylie. Aktuelle Derm 1997;23:120-1.

36. Bardazzi F, Neri I, Roone B, Patrizi A. Pachydermodactylie: 7 nouveaux cas. Ann Dermatol Venereol 1998;125:247-50.

37. Tompkins SD, McNutt NS, Shea CR. Distal pachydermodactyly. J Am Acad Dermatol 1998;38(2 Pt 2):359-62.

38. Woodrow SL, Burrows NP. Pachydermodactyly in association with Asperger syndrome. Clin Exp Dermatol 2003;28:674-5.

39. Marcilly MC, Balme B, Luaute JP, Skowron F, Berard F, Perrot H. Pachydermodactylie associee a une pachydermie plantaire. Ann Dermatol Venereol 2003;130:777-80.

40. Chamberlain AJ, Venning VA, Wojnarowska F. Pachydermodactyly: a forme fruste of knuckle pads? Ausralas J Dermatol 2003;44:140-3.

41. Pereira JM, Pereira FC, Pereira VN. Interphalangeal pads on pachydermodactyly. An Bras Dermatol 2004;79:313-21.

42. Saka B, Mezdegi A, Ozturk A, Erten N, Cefle K, Palanduz S. Two siblings with distal pachydermodactyly. Clin Exp Dermatol 2005;30:707-9.

43. Yebenes M, Garcia X, Gilaberte M. Acquired fusiform swelling of the fingers. Arch Dermatol 2005;141:1035-6.

44. Blanes M, Betlloch I, Pastor N, Banuls J. Classic pachydermodactyly: study of 5 cases in young boys. J Am Acad Dermatol 2005;52(3 Suppl):153.

45. Okuyama R, Kagatani S, Tagami H, Aiba S. Pachydermodactyly in an elderly Japanese patient showing distal involvement of the fingers. Dermatology 2006; 213:177-8.

46. Park JH, Lee CW. A case of pachydermodactyly treated by surgical excision. Korean J Dermatol 2006;44:369-71.

47. Tollefson MM, Wright TI, Davis DM. Soft-tissue swelling around the proximal interphalangeal joints bilaterally: pachydermodactyly. Arch Dermatol 2008;144:1651.
48. Yeh YL, Lin HS, Hsiao YP, Shih HC, Tsai BJ, Yang JH. Pachydermodactyly, a case report. Dermatol Sinica 2008;26:248-51.

49. Kumar P, Gharami R. Pachydermodactyly: a classical case of this rare disease. J Turk Acad Dermatol 2009;3(4):93401L.

50. Vale LR, Coeli FR, Michalany N, Hassun KM, Porro AM. Transgrediens pachydermodactyly: report of a case. An Bras Dermatol 2009;84:190-3.

51. Cabanillas M, Monteagudo B, Leon-Muinos E, Suarer-Amor O. Pachydermodactyly in a young girl: cutaneous manifestation of a psychiatric disorder? Pediatr Dermatol 2010;27:306-8.

52. Morales Callaghan AM, Horndler Argarate C, Garcia Latasa de Aranibar FJ, Zubiri Ara ML. Pachydermodactyly: a rare form of acquired digital fibromatosis. Actas Dermosifilliogr 2010;101:652-4.

53. Hunt R, Mandal R, Walters R, Schaffer JV. Pachydermodactyly. Dermatol Online J 2010;16:5.

54. Rachowska R, Filipowska-Gronska A, Werynska-Kalemba M, Božek A, Filipowska B, Zajecki W, et al. Pachydermodactyly a case report. Postepy Dermatol Alergol 2010;27:500-3.

55. Seo SH, Sung HW. A case of pachydermodactyly. Ann Dermatol 2011;23(2):258-61.

56. Zamanian A, Ansar A. Pachydermodactyly, a new case from Iran. Dermatol Online J 2011;17:8.

57. Castori M, Paradisi A. Pachydermodactyly with mild features of heritable connective tissue disorder and no sign of emotional distress. Clin Exp Dermatol 2011;36:690-2.

58. Sagransky MJ, Pichardo-Geisinger RO, Munoz-Ali D, Feldman SR, Mora DC, Quandt SA. Pachydermodactyly from repetitive motion in poultry processing worker. Arch Dematol 2012;148:925-8.

59. Yang MF. Pachydermodactyly in a patient with Tourette syndrome. J Am Acad Dermatol 2012;66(4 Suppl 1):AB59.

60. Requena CB, Miot HA, Marques MEA, Miot LD. Case for diagnosis. Pachydermodactyly. An Bras Dermatol 2014;89:359-60.

61. Plana Pla A, Bassas Vila J, Toro Montecinos MA, Ferrrandiz Foraster C. Pachydermodactyly successfully treated with triamcinolone injections. Astas Dermosifiliogr 2014;105:319-21.

62. Carrascosa R, Godoy A, Gordillo C, de Argila D. Pachydermodactyly in a patient with generalized anxiety disorder and tics. Actas Dermosifiliogr 2014;105: 625-6.

63. Martin JC, Rennie JA, Kerr KM. Pachydermodactyly: confused with JCA. Ann Rheum Dis 1992;51:1101-2.

64. Rai A, Zaphiropoulos GC. An unusual case of peri-articular soft tissue finger swelling in an adolescent male: pachydermodactyly or pachydermoperiostosis? Br J Rheumatol 1994;33:677-9.

65. Ye S, Chen SL, Ding YQ, Lin F, Guo Q, Bao CD. Pachydermodactyly: six new cases from China. J Clin Rheumatol 2005;11:72-5.

66. Wollina U. Chewing pads versus pachydermodactyly: comment on the clinical image by Akikusa et al. Arthritis Rheum 2005; 2:2953-4.

67. Akikusa JD, Weinstein M, Laxer RM. Clinical images: pachydermodactyly. Arthritis Rheum 2005;52:990.

68. Anandacoomarasamy A, Bak HS, Peduto A, Manolios N. Magneting resonance imaging in pachydermodactyly. J Rheumatol 2005;32:2239-41.

69. Carpentier KG, Sevenants L, Wouters CH, Morren MA. 
Pachydermodactyly may mimic juvenile idiopathic arthritis. Clin Exp Rheumatol 2005;23:725.

70. Garcia-Miguel J, Blanch-Rubio J, Calvo N, Iglesias M. Young male with pachydermodactyly: imaging findings. Rheumatol Clin 2005;1(2):131-3.

71. Sandobal C, Kuznietz A, Varizat A, Roverano S, Paira S. Pachydermodactyly: four additional cases. Clin Rheumatol 2007;26:962-4.

72. Taylor-Gjevre R, Saxena A, El Maadawy S, Classen D, Nair B, Gjevre J. A case of deforming pachydermodactyly. J Clin Rheumatol 2009;15:78-80.

73. Schutz C, Morbach H, Weiss T, Pfeiffer C. Atypical pachydermodactyly. In: Abstractband zum 38. Kongress der Deutschen Gesellschaft fur Rheumatologie, 2010 Sep 1518, Hamburg, Germany. Berlin: Deutsche Gesellschaft fur Rheumatologie; 2010:KR20.

74. Prieto D, Gallego E, Lopez-Navarro N, Matilla A, HerreraCeballos E. Pachydermodactyly: an uncommon acquired digital fibromatosis. J Clin Rheumatol 2011;17(1):53-4.

75. Dias JM, Costa MM, Romeu JC, Soares-Almeida L, Filipe P, Pereira da Silva JA. Pachydermodactyly in a 16-year-old adolescent boy. J Clin Rheumatol 2012;18(5):246-8.

76. Ulusoy H, Tas NP, Akgol G, Gulkesen A, Kamanli A. Unusual unilateral presentation of pachydermodactyly: a case report. Rheumatol Int 2012;32:1747-50.

77. Kariotis R, Vrtikova E, Hapčova M, Zwerina J, Dallos T. Pachydermodactyly. Z Rheumatol 2013;72:482-5.

78. El- hallak M, Lovell D. Pachydermodactyly mimicking juvenile idiopathic arthritis. Arthr Rheumatol 2013;65(10):2736.

79. Kisaarslan AP, Gorkem SB, Livcigerci F, Gunduz Z, Poyrazoglu H, Dusunseln R. Pachydermodactyly - a disease confused with polyarticular juvenile idiopathic artritis. Ann Paediatr Rheumatol 2014;3:138-40.

80. Fleeter TB, Myrie C, Adams JP. Pachydermodactyly: a case report and discussion of the pathologic entity. J Hand Surg Am 1984;9:764-6.

81. Aoki K, Iida H, Umeda T, Katayama I, Nishioka K. A case of pacyhydermodactyly. Jpn J Plast Reconstr Surg 1994;37:109-13.

82. Glicenstein I, Costa R. Pachydermodactyly: a report of two cases. Chir Main 2004;23:205-7.

83. Al Hammadi A, Hakim M. Pachydermodactyly: case report and review of the literature. J Cutan Med Surg 2007;11:185-7.

84. Cartier H, Guillet MH, Schollhammer M, Guillet G. Pachydermodactilie de 1 adolescent expression d un mal-etre. Arch Pediatr 1996;3:1091-4.

85. Calikoglu E. Pseudo-knuckle pads: an unusual cutaneous sign of obsessive-compulsive disorder in an adolescent patient. Turk J Pediatr 2003;45:348-9.

86. Fathalla BM, Goldsmith DP. Pachydermodactyly mimics polyarticular juvenile idiopathic arthritis. J Pediatr 2009;155:931-3.

87. Thakkar V, Singh-Grewal D. Swollen digits. Diagnosis: pachydermodactyly. J Paediatr Child Health 2010;46: 356.

88. Castellanos Gonzales M, Sanz Motilva V. Pachydermodactyly: case report. Arch Argent Pediatr 2011;199(5):e97-9.

89. Coughlin CC, Perman MJ. Teenage male with "swelling" on the fingers. Infect Dis Childr 2014 Oct.

90. Reichert CM, Costa I, Barsky SH, Claysmith AP, Liotta LA, Enzinger FM, et al. Pachydermodactyly. Clin Orthop Relat Res 1985;194:252-7.

91. Birman MV, Lee DH. Factitious disorers of the upper extremity. J Am Acad Orthop Surg 2012;20;78-85.

92. Higuchi C, Tomita T, Yoshikawa H. Pachydermodactyly treated with tranilast in a young girl. Case Rep Orthop 2014;ID 132854, 4 page.

93. McKusick VA. Pachydermodactyly, familial [database on the Internet]. OMIM. c1966-2015 [cited 2015 Jan 15]. Available from: http://www.omim.org/entry/600356

94. Brousse C, Rybojad M, Piette AM, Gepner P, Chapman A. Pachydermodactylie: une observation. Rev Med Interne 1994;15:412-4.

95. Bugatti L, Filosa G. Pachydermodactyly. A case report. In: INABIS '98 - 5th Internet World Congress for Biomedical Sciences; 1998 Dec 7-16, McMaster University Hamilton, Ontario, Canada. [cited 2015 Jan 15]. Available from: http:// www.mcmaster.ca/inabis98/dermatology/bugatti0112/index. html

96. Mansouri P, Safaii Naraghi Z, Seirafi H, Mortazavi MR. Pachydermodactyly: report of two cases. Acta Med Iran 1999;37(4):232-6.

97. Small S, Murthy V, Sridhar AV. A 12-year-old boy presenting with unilateral proximal interphalangeal joint swelling. BMJ Case Rep 2011; doi: 10.1136/bcr. 01.201. 3719.

98. Yang J. Clinical analysis of 10 cases of pachydermodactyly. Jilin Med J 2011-05.

99. Chen CK, Shyur SD, Chu SH, Huang LH, Kao YH, Liu LC. Pachydermodactyly: three new cases in Taiwan. J Microbiol Immun Infect 2012 Dec 3. pii: S1684-1182(12)00207-1. doi: 10.1016/j.jmii.2012.09.002.

100. Sinha NK, Ling SP, Nema SK, Pai DR. Pachydermodactyly does not need rheumatologic work-up. J Postgrad Med 2013;59(4):335-6. 


\section{Pahidermodaktilija - prikaz slučaja i pregled literature}

\section{Sažetak}

Uvod. Pahidemodaktilija (PDD) je benigna digitalna fibromatoza za koju je karakteristično asimptomatsko progresivno lateralno zadebljanje periartikularnog mekog tkiva, obično simetrično lokalizovanog oko proksimalnih interfalangealnih zglobova (PIP) drugog, trećeg i četvrtog prsta ruku: tako dolazi do simetričnog, oticanja kože dorzalnih i lateralnih strana proksimalnih falangi kažiprsta, srednjeg prsta i domalog prsta. Najčešće se javlja kod mladih adolescenata i verovatno je posledica ponovljene mehaničke stimulacije; nekad se javlja i kao posledica opsesivno-kompulzivnog poremećaja, ali se mora razlikovati od obsesivnog 'chewing pads' (eng. grickanje prstiju). Difuzno oticanje zahvaćenog prsta koje uključuje dermis pored epidermisa, jasno odvaja PDD od 'knuckle pads' (bokserski jastučići), kalusa, profesionalnih kalozita, itd. Opisani su slučajevi u kojima su oboleli članovi unutar iste porodice, PPD i "knuckle pads" mogu biti istovremeno prisutni kod jedne iste osobe.

Prvi opis bolesti dali su Baseks (Basex) i saradnici 1973. kao pachydermie digitale. Termin pachydermodactyly predložio je Verbov 1975. i potiče od grčkih reči pachy (thick - zadebljanje), dermo (koža) i dactilos (prst).

Prikaz slučaja. U radu je prikazan muškarac star 19 godina, po zanimanju student, koji je u 12. godini života primetio povećanje obima trećeg i četvrtog prsta leve ruke. Do kraja 14 . godine bili su izmenjeni svi prsti sem palčeva na obema rukama i od tada je stanje uglavnom ostalo isto. Pojavu ovih promena povezao je sa udaranjem lopte, kao i sa tim da ima običaj da trlja i „lomi“ prste. Nama je upućen sa uputnom dijagnozom periartikularne artropatije posle pregleda ortopeda, reumatologa i fizijatra, a radi isključenja psorijaze i/ ili seboroičnog dermatitisa kapilicijuma. Pacijent je na prijemu negirao postojanje drugih oboljenja i izjavio da u porodici nije bilo obolelih srodnika.

Opšte stanje pacijenta na prijemu bilo je u fiziološkim granicama. Dermatološki status je ukazao na: izmenjen oblik i obim svih prstiju obe šake, osim oba palca, u nivou proksimalnih falangi; normalan izgled distalnih delova svih prstiju; u nivou prvih interfalangealnih zglobova zadebljanje; hipertrofija, skoro simetrična na obe lateralne strane (ulnarna i radijalna) falangi svih zahvaćenih prstiju, osim oba kažiprsta, gde je hipertrofija zahvatila samo ulnarnu stranu (Slika 1). Palpatorno, promenjeni delovi su bili bezbolne, homogene teksture i elastične konzistencije, pokretni u odnosu na susedne koštane strukture. Svi zglobovi su pokazivali nepromenjenu funkciju.

Svi ispitivani relevantni laboratorijski parametri pokazali su vrednosti koje su bile u granicama referalnih vrednosti, uključujući faktore inflamacije, serumski nivo imunoglobulina, C3 i C4 komponente komplementa, prisustvo antinuklearnih antitela $\mathrm{i}$ imunoglobulina.

Ehosonografija zglobova šaka: osteoartikularne površine bez ehosonografskih znakova za defekte; ne uočavaju se periartikularne fokalne promene, osim inbibicije mekih tkiva; sinovije medijalnih interfalangealnih zglobova zadebljane; povećanje intraartikularne sinovijalne tečnosti.

RTG šaka u oba pravca: koštana građa prvog reda očuvana (Slika 2).

Patohistološki nalaz: u epidermisu izražena hiperkeratoza i akantoza; epidermo- dermalna granica zaravnjena; dermis zadebljao, hipocelularan, retki fibroblasti okruženi su širokim hijalinizovanim trakama kolagene strome; adneks kože odsutan.

Intraleziono ubrizgavanje rastvora triamcinolona $\mathrm{u}$ toku tri meseca dovelo je do neznatnog smanjenja obima tretiranog prsta. Savetovali smo pacijenta da izbegava mehaničke traume, trljanja i „pucanja“ prstiju.

Diskusija i pregled literature. Kako je PDD oboljenje koje se javlja u pubertetu i manifestuje se uglavnom asimptomatskim promenama u predelu proksimalnih interfalangealnih zglobova (PIP) ruku u vidu uvećanja tkiva oko zglobova, sa mogućim promenama na koži, to su u dijagnostiku i lečenje uključeni lekari različitih specijalnosti (reumatolozi, ortopedi, pedijatri, dermatolozi, hirurzi). Radovi koji se odnose na PDD, objavljivani su i u časopisima koji nisu isključivo usmereni samo na dermatologiju, a to se može tumačiti multidisciplinarnim pristupom obolelima (Tabela 1). Dva rada predstavlju opsežne analize do tada objavljenih radova: prvi iz su 2009. objavili Beltramineli (Beltraminelli) i saradnici, a drugi su 
2014. godine objavili Dalos (Dallos) i saradnici. U prvoj studiji izvršena je analiza 55 radova sa 88 bolesnika, dok je druga obuhvatila još 17 objavljenih radova, sa ukupno 121 bolesnikom registrovanim do tada. Novim pretraživanjem registrovali smo još 28 radova sa 45 obolelih. Znači, od Baseksa i saradnika do danas, objavljeno je o PDD najmanje 100 radova u kojima je prikazano 165 bolesnika. S našim prikazom, to bi bilo 101 rad sa 166 bolesnika.

Odsustvo subjektivnih tegoba, samolimitirajući tok, zaustavljanje progresije oboljenja u adolescentnom dobu, odsustvo trajnih sekvela, predstavljaju faktore zbog kojih se pretpostavlja da je stvarna prevalencija PDD realno viša, te da PDD nije tako retka. Bolest se najčešće javlja u ranom pubertetu kod osoba muškog pola, kao što je to slučaj kod našeg pacijenta: u starijem uzrastu, može biti posledica neprepoznavanja oboljenja. U literaturi su opisana dva slučaja bolesti od samog rođenja i samo četiri slučaja kod starih osoba. Bolest se javlja sporadično, ali su opisani i familijarni slučajevi, a u tri slučaja se radilo o transgredijentnoj formi PDD. Etiologija bolesti nije u potpunosti razjašnjena: na moguću individualnu genetsku predispoziciju, koja je verovatno esencijalna, nadovezuje se više precipitirajućih faktora. Najznačajnja je ponavljana mehanička trauma usled pokreta sličnih tikovima, kao što je istezanje, trljanje ili „pucketanje“, „lomljenje“ prstiju, bilo da se radi o zdravim osobama ili onima sa opsesivno-kompulzivnim poremećajem. U literaturi su objavljeni slučajevi PDD čijoj pojavi nisu prethodile ni trauma ni frikcija. Značajno češća pojava PDD kod dečaka na početku puberteta u odnosu na osobe ženskog pola i starijeg uzrasta, ukazuje na patogenetske uloge androgenih hormona; ne isključuje se i mogući uticaj hormona rasta i tiroidne hipofunkcije). Zbog česte pojave PDD kod osoba sa opsesivno-kompulzivnim i neurološkim poremećajima postoje zagovornici da se PDD stavi na listu kutanih manifestacija psiholoških poremećaja. Kod našeg pacijenta je postojala navika da trlja i „lomi“" prste, ali nije imao nikakve psihogene poremećaje.

Pored tipične kliničke slike, mogu biti zahvaćene i dorzalne i/ili ventralne strane prstiju. Opisana je i distalna varijanta, sa zahvatanjem distalnih falangi i metakarpofalangealnih zglobova, sa fibromatoznim zadebljanjem ili sa čvrstim nodusima. Promene su obično simetrične, ali mogu biti asimetrične u raznom stepenu, od različitog broja i stepena zahvaćenih zglobova na levoj i desnoj ruci do zahvatanja samo pojedinih zglobova u tzv. lokalizovanoj formi PDD. Opisana je i monoartikularna varijanta PDD. Peti prst i palacsu retko zahvaćeni; prsti nogu nikada nisu zahvaćeni, a plantarna pahidermija je opisana kod bolesnika sa PDD koji je imao akrocijanozu. Koža na obolelim prstima može biti lihenificirana, sa lakom deskvamacijom ili hiperkratozom, nekad i umereno eritematozna, retko bolna. Nije registrovana pojačana osetljivost, svrab, žarenje jutarnja ukočenost ili redukovana pokretljivost. Objavljen je samo jedan deformantni slučaj PDD sa neerozivnom subluksacijom interfalangealnog zgloba. Kod prikazanog bolesnika bila su zahvaćena oba lateralna aspekta, ulnarni i radijalni delovi kože proksimalnih interfalangealnih zglobova i proksimalnih falangi II, III, IV i V prsta obeju ruku, sem kažiprsta, gde su promene bile samo na ulnarnim stranama. Površina kože je bila lako hiperkeratotična. Nije imao poremećaj funkcije, niti bolove.

Zbog heteregenosti kliničke slike i opisanih familijarnih slučajeva, izvršena je klasifikacija bolesti na pet tipova: 1. klasični tip (zahvaćeno više PIP kao posledica mikrotraume); 2. lokalizovani tip (zahvaćen jedan zglob); 3. transgredijentni (zahvata metakarpofalangealnu regiju); 4. familijarni (zahvaćeno više članova iste porodice) i 5 . udružen sa tuberoznom sklerozom.

Prema Čenu (Chen), dijagnostički kriterijumi su: pacijent je bez simptoma; jutarnja ukrućenost je odsutna; bol pri pokretima i osetljivost na palpaciju su odsutni; zadebljanje prsta je radijalno ili ulnarno, retko cirkumskriptno; laboratorijski testovi nisu značajni; radiografski se nalazi samo zadebljanje mekog tkiva. Sa ovim tipičnim nalazom dodatna istraživanja retko su potrebna za postavljanje dijagnoze PDD.

U lečenju PDD nema efikasnog medikamentnog tretmana. Operativnom resekcijom fibroznog tkiva postignuti su dobri rezultati bez recidiva. Dobre rezultate dala je i intraleziona aplikacija triamcinolona, dok su pokušaji lokalne aplikacije topikalnih kortikosteroida uglavnom ostali bezuspešni. Higuči (Higuchi) je objavio dobre rezultate posle primene antialergijskog leka tranilasta, koji izaziva inhibiciju sinteze kolagena u koži, u dozi od 300 mg dnevno u toku 6 meseci. Eliminacija mehaničke stimulacije može dovesti do spontane regresije. Bolest je benignog karaktera sa hroničnim tokom. Prognoza je varijabilna. 
Moguća je stabilizacija u kasnijim godinama posle višegodišnje progresije.

Zaključak. Prikazana je osoba muškog pola kod koje se pahidermodaktilija manifestovala na proksimalnim falangama svih prstiju osim palčeva obe šaka kao posledica trljanja i „pucketanja“ zglobova prstiju. U porodici nije bilo obolelih. Intralaziona aplikacija triamcinolona na jednom prstu dovela je do poboljšanja. Dat je savet da se prekine sa mehaničkom traumom. Pregled dostupne literature od 1973. do 2014. godine omogućio je bolje sagledavanje kliničkih varijanti oboljenja.

\section{Ključne reči}

Fibrom; Dermatoze šake; Deformiteti šake; Prsti; Neoplazme mekih tkiva; Kumulativni traumatski poremećaj 